\title{
СЛОЖЕНИ ПРИДЕВИ У МАРЕТИТЕВОМ ПРЕВОДУ ХОМЕРОВОГ СПЕВА ИЛИЈАДА
}

\begin{abstract}
Рад се бави творбеном и семантичком анализом сложених придева које употребљава Томо Маретић преводећи од 12. до 15. певања Хомеров спев Илија$\partial a$. Циљ овог истраживања јесте да се утврди мотивација, грађење и фреквентност ових придева, као и да се одреди доминантан поступак преводиоца. Очекује се да ће централна поглавља спева пуна догађаја и ликова обиловати и разноврсним придевским сложеницама. Ексцерпиран је укупно 51 пример. Ради прецизније анализе сви придеви су класификовани у четири групе према врсти речи којој припада прва саставница сложенице. Најбројнији су сложени придеви у којима је на првом месту придевска основа. Доминантан је спојни вокал -o-, а и суфикси се неретко срећу (-ø и - $a H /-н u)$, те су многи придеви из грађе добијени сложено-суфиксалном творбом. У погледу значења највише примера описује јунаке и богове из Илијаде. Поједини сложени придеви добијају лексикализовано значење (нпр. ветроног), док већина чува семантику својих саставница. Испитивање фреквентности показује понављање анализираних примера током Хомеровог спева (брзоног је забележен 110 пута). Анализом је уочен и Маретићев поступак да придевску сложеницу веже за одређену именицу, па да их тако као синтагму понавља.
\end{abstract}

Кључне речи: сложени придеви, слагање, сложено-суфиксална творба, Илија$\partial a$.

\section{1. Увод}

Монументално дело античке књижевности Илијада оставило је значајан траг у историји књижевности и привлачи пажњу бројних проучавалаца књижевне речи, али и преводилаца. Томо Маретић један је од оних који су превели Хомерову Илијаду на наш језик. Његов превод је карактеристичан по језичком богатству, које се огледа у специфичним лексичким јединицама проистеклим из ауторовог пера. Оно што посебно Маретићев стил чини препознатљивим јесте честа употреба сложених придева које углавном преводилац сам твори слажући речи домаћег порекла. Придевске сложенице у овом преводу Хомеровог спева Илијада доприносе снажнијем утиску чи-

\footnotetext{
${ }^{1}$ dj.sunjevaric-15757@filfak.ni.ac.rs
} 
талачке публике откривајући јој дубљи смисао упечатљивим дочаравањем света књижевног дела. Разноврсношћу и учесталом употребом сложених придева, Т. Маретић нуди добар материјал за језичка истраживања.

Сложени придеви у српском језику посматрани су и дефинисани у досадашњој литератури на различите начине (JOVANOVIĆ 2002). И. Клајн у својој Творби речи у савременом српском језику полази од Стевановићевог одређења сложеница ${ }^{2}$, које се заснива на „идеји о настанку сложеница од синтагми" (2002: 22). На тај начин уводи се синтаксички план у проучавање сложеница, са посебном освртом на међусобни однос саставних делова. Да се сложенице управо перципирају на синтагматском нивоу потврђује истраживање помоћу упитника које је спровео В. Ж. Јовановић (2014). Испитаници су сложенице доживљавали као синтагме или скраћене реченице, а уместо тих облика радије би употребили две речи или целу реченицу. Семантика такође има важну улогу у перципирању ових лексема. „Reči koje sadrže korene koje su poznate govornicima su obično prihvatljivije i lakše za prepoznavanje i razumevanje" (JOVANOVIĆ 2014: 260-261). Говорници једног језика при првом сусрету са неком сложеницом могу парафразирати њено значење на основу саставних елемената који је чине. Међутим, значење сложенице није увек једнако простом споју значења мотивних речи од којих је настала. Придевска сложеница може бити лексикализована (нпр. тврдоглав 'који упорно остаје при своме, који не уважава никакве разлоге и доказе сем својих, задрт, својеглав ${ }^{3}$; широкогруд 'који има много разумевања за друге, увиђаван, стрпљив ${ }^{\circ}$. Тако настају егзоцентричне сложенице, које имају потпуно независно значење од семантике њихових саставница, те богате речник једног језика.

Говорећи о слагању, Клајн истиче да словенски језици „нису нарочито склони композицији” (2002: 15). Томе умногоме доприноси систем српског језика кога одликују бројни падежни облици, али и категорије придева као што су вид или степен поређења. Типови усложњавања придева у српском језику нису продуктивни, јер настају „,polisilabične i polimorfemske leksičke kreacije sa jedinstvenim akcentom" (JOVANOVIĆ 2007: 65). У грађењу сложених придева учествују основе двеју речи које слагањем творе нову лексему. На првом месту сложенице може се наћи основа именице, придева, заменице, броја, глагола или прилога, док је у другом делу поред именичке и глаголске основе могуће наићи на цео придев. Типичан је случај са придевским сложеницама које означавају неку нијансу, где се на другом месту обавезно јавља придев за боју (нпр. светлоплав, тамносмеђ). Прва компонента оваквих сложеница служи да модификује придев у другом делу. У српском језику

\footnotetext{
2 „Сложенице су речи које су постале срастањем двеју или више посебних речи у једну” (СТЕВАНОВИЋ 1986: 399).

3 Значења примера утврђена су на основу Речника српскохрватскога књижевног језика (PMC).
} 
сложенице се пишу састављено. Обично долази до спајања основе речи из првог дела са придевом из другог. Међутим, много је чешћа ситуација када се између тих саставница нађе спојни вокал. Улога спојног вокала у творби сложених придева је чисто везивна, али он и олакшава изговор сложенице разбијањем сугласничке групе у средини речи. Доминантан је спојни вокал -о-. Поред њега јавља се -e-, а и други вокали којима се не може потврдити статус спојног вокала (КЛАЈН 2002: 25). Ова појава карактеристична је и за друге словенске и суседне језике (NEHRING 2006). Сложени придеви настају и сложено-суфиксалном творбом. Када је друго место придевске сложенице предвиђено за неку именицу или глагол, обавезно се на њихову основу додаје придевски суфикс. „Суфиксалне морфеме сложених придева остварују њихово морфолошко обликовање као одређену врсту речи (на основу чега ми их сврставамо у придеве), али оне не сигнализују ништа више" (ЛАШКОВА 1987: 140). Као суфикс код таквих придева најчешће се може

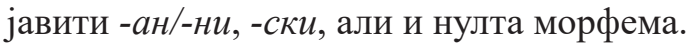

Предмет истраживања у овом раду чине сложени придеви који се јављају од 12. до 15. певања Хомерове Илијаде у Маретићевом преводу. Грађа је ексцерпирана из централних поглавља Хомеровог спева, јер се у њима приказују борбе, односи међу боговима, а присутно је мноштво јунака. Очекује се да је баш то дало доста повода преводиоцу за креативност и уношење сложених придева. Циљ анализе јесте да се утврди како су добијене издвојене сложенице и шта их је мотивисало, као и да се одреди доминантан поступак Тома Маретића у њиховом стварању. Пажња ће бити усмерена и на фреквентност употребе тих лексема у целом делу, које обухвата 24 певања.

\section{2. Анализа грађе}

Грађу чини 51 сложени придев које је Томо Маретић користио преводећи од 12. до 15. певања Хомерову Илијаду. Готово да не може проћи ни сто стихова, а да се не наиђе на макар једну придевску сложеницу. Ради детаљније творбене и семантичке анализе ексцерпираних примера, класификоваћемо их у четири групе према првој компоненти која улази у састав сложенице: сложени придеви са именицом, придевом, прилогом и бројем на првом месту.

\section{1. Сложени придеви са именицом у првом делу}

Када се као прва компонента сложеног придева нађе именичка основа, на другом месту јавља се цео придев или именичка/глаголска основа са суфиксом. Све ово потврђује и корпус, у коме се проналази чак 19 примера овог типа, што чини $37 \%$ издвојених сложеница.

Пример громогласан састављен је од именичке основе гром-, спојног вокала -о- и придева гласан. Значење ове сложенице изводи се на основу 
семантике мотивних речи: 'гласан као гром . Маретић је овим придевом описао бога Зевса, бога громова и муње, те се само при његовом помену употребљава та придевска сложеница.

Више примера настаје сложено-суфиксалном творбом по моделу $И_{\mathrm{O}}{ }^{\mathrm{C}}$ $+И_{\mathrm{O}}+$ суфикс. $^{4}$ У српском језику нема много оваквих сложених придева, а обично се јављају они са саставницом -лик на другом месту. Извор бележи пример боголик ${ }^{5}$, а као и остале придевске сложенице које имају овакав други део, означава да је нешто по изгледу слично (налик) некоме/нечему (у овом случају богу). Овај придев има спојни вокал -о- који повезује две именичке основе, а у саставу сложенице налази се и нулти суфикс. Придеви грађени по овом моделу у свом другом делу могу садржати основу именице са значењем неког дела тела. Такви су примери волоок, ветроног, медоног и коњогриван. Другу саставницу ових сложеница чине творбене основе именица око, нога и грива. Све имају спојни вокал -о-, док, када је реч о суфиксу, придев коюогриван садржи суфиксалну морфему -aн/-нu, за разлику од осталих сложено-суфиксалних твореница са нултим суфиксом. Придевом волоок описане су жене у Хомеровом спеву, међу којима се посебно истиче Хера као главни носилац тог епитета. Преводилац је коришћењем ове сложенице имао намеру да дочара крупне, прелепе Херине очи поредећи их са воловским. Сложеним придевом ветроног сугерише се брзина попут ветра која карактерише Ириду, те се Маретић послужио метафором и сложио именице ветар и нога. Понеки коњ се у делу описује као медоног, што је позитивно, јер има ноге 'од меда' ${ }^{6}$ од бакра, бронзе. Придевска сложеница чија друга компонента означава део тела животиње је коњогриван и односи се на шлем. На основу њега можемо замислити изглед тог шлема који је украшен гривом коња. У грађи постоји још један пример сложеног придева који има две именчке основе, спојни вокал и суфикс. То је златотрон, а упућује на Херу и Артемиду. Први део ове сложенице може се тумачити и као редукована придевска основа, јер је њихов трон 'од злата' и 'златан'. Спојни вокал је -о-, а на именичку основу трон- додат је нулти суфикс. Према речима И. Клајна, сложени придеви настали по овом моделу представљају „двоименичке сложенице у придевској функцији” (2002: 92).

Све остале придевске сложенице из корпуса са именицом у првом делу имају глаголску другу компоненту. Најчешће се јавља редукована основа глагола носити, као у примерима копљоносан и ититоносан. Оба ова придева одређују јунаке-ратнике, племена и чете, који у бојевима носе оружје

\footnotetext{
${ }^{4}$ Творбени модели дати су по узору на оне које наводи И. Клајн (2002).

${ }^{5}$ Т. Маретић сложеним придевом боголик одређује чак 28 јунака у целом спеву. То су: Дејфоб, Сарпедон, Александро, Полифет, Радамант, Трасимед, Арет, Хромиј, Неоптолем, Ганимед, Полидор, Феникс, Пријам, Местор, Политем, Еуријал, Поликсен, Мигдон, Пандар, Махаон, Полиник, Ереуталион, Ликофонт, Ајас, Одисеј, Молион, Сок и Патрокло.
}

6 Лексема мёд има значење 'бакар; легура бакра и цинка, месинг' (РМС). 
попут копља или штита. Суфикс - $a н /-н и$ је најпродуктивнији у творби ових сложених придева. Улогу спојног вокала и овде преузима -о-. Са истим првим делом као сложени придев копљоносан јавља се лексема копљометан. Њоме се означава јунак који је 'вешт бацању копља'. Други део овог придева чини редукована основа глагола метати ('бацати'). По овом моделу настала је и сложеница ветрородан. Маретић овај придев употребљава уз именицу вал чиме наглашава да га је ветар створио ('рођен је од ветра ${ }^{\circ}$ ). Још два примера из грађе издвајају се по истом првом делу: земљомичан и земљотресан. И један и други придев користе се само када је реч о богу мора Посејдону, јер се веровало да сви потреси долазе баш из мора. Глаголи мицати и трести који су учествовали у мотивацији ових сложених придева указују на померање Земље. Коње у спеву описује и придевска сложеница коловозан, а односи се на оне коње који вуку (возе) кола. У централним певањима Илијаде помињу се и Трачани, па пошто су они познати по добром узгајању и храњењу коња, окарактерисани су придевом коњогојан. Ова сложено-суфиксална твореница грађена је од именичке основе, спојног вокала -о-, редуковане глаголске основе и суфикса - $а н /-н и$. На исти начин настао је и придев људогубан од мотивних речи људи и губити. Овом сложеницом одређује се бој, јер тада највише страдају људи ('погубан је за људе'). Уместо синтаксичке конструкције 'лађа која плови морем', Т. Маретић уноси сложени придев мороплован да би описао ту лађу. Још један од придева насталих по истом моделу (И ${ }_{\mathrm{O}}{ }^{\mathrm{C}}+\Gamma_{\mathrm{O}}+$ суфикс) јесте мукопатан. Овај придев је синониман лексеми мукотрпан, с тим што се место глагола трпети у другом делу јавља патити. Преводилац се определио за експресивнији глагол како би нагласио да јунаци и бојници с муком пате. Заједничка карактеристика придева са именичком основом у првом и редукованом глаголском у другом делу је исти спојни вокал -о- и суфикс - $a \mu /-н и$. Једина придевска сложеница која се мало разликује од претходних је медокован. Поред именичке основе и спојног вокала -о-, ова лексема садржи трпни придев глагола ковати у другом делу. Њоме се означава копље које је ковано од меда (бакра).

Сложени придеви са именицом у првом делу заузимају више од трећине целокупне грађе. Сви анализирани примери садрже спојни вокал -о- који именичку основу из првог дела повезује са другом компонентом сложенице. На другом месту два примера имају придев, од којих је један глаголског порекла. Остали су добијени сложено-суфиксалном творбом, те у састав придева улази и суфикс (5 примера има -ø, а 12 суфикс -ан/-ни). Значења придевских сложеница проистичу из самих саставница, а једино се у примеру ветроног уочава лексикализовано значење 'брз' .

\footnotetext{
7 Занимљиво је да придев ветрородан преводилац користи и уз копље са напоменом да је то копље направљено од дрвета са врха планине где су јаки ветрови.
} 


\section{2. Сложени придеви са придевом на првом месту}

Другу групу ексцерпираних примера чине придевске сложенице које у првом делу имају придевску основу. Таквих је 22 , те тиме обухватају $43 \%$ целокупног корпуса. Грађа показује да се обично код таквих сложеница у другом делу налази цео придев или именичка основа са суфиксом.

Само два сложена придева са придевском основом у првом делу имају придев и на другом месту. То су злопак и крвавоирвен. Први пример представља напоредну (координативну) сложеницу, јер су оба мотивна придева равноправна. Пошто се односи на Херину превару, сложени придев се може парафразирати на следећи начин: зла и опака превара. Насупрот њој, друга сложеница је одредбена (субординативна) и представља једну боју. Први део модификује други и служи да означи нијансу, па ирвен постаје додатно спецификован лексемом крвав. Маретић овим примером боји змију која је тако црвена као да је крвава. У процесу слагања придева крвавоцрвен учествовао је и спојни вокал -о-, док он изостаје у примеру злопак.

Већина придевских сложеница добијена је по моделу $\Pi_{\mathrm{O}}{ }^{\mathrm{C}}+\mathrm{U}_{\mathrm{O}}+$ суфикс. Придев одређује именицу и стоји испред ње, а управо је такав поредак њихових основа у сложеницама овог типа. Стога је ово и најпродуктивнији творбени тип за грађење сложених придева у српском језику. ${ }^{8}$ Чак четири примера има исти први део: дуговрат, дугогрив, дугокрил и дугосен. Придевска основа дуг- налази се на првом месту, док други део после спојног вокала -о- чине основе именица врат, грива, крило и сен. Прва три сложена придева, чији други део именује део тела, служе за описивање животиња. Тако је птица са дугим вратом лабуд, а соко има дуга крила. Дугу гриву поседује лав, те и носи епитет дугогрив. Сложеница дугосен упућује на копље које је толико дугачко да, када се баца, оставља велику сен(ку) на земљи. Наведена четири придева садрже и нулти суфикс који се додаје именичкој основи. Сложеница са антонимом придева дуг у првом делу јесте кратковечан. Међутим, овде придев из првог дела нема просторно значење, већ је цела сложеница лексикализована и односи се на проток времена. Поред придевске основе, у састав овог сложеног придева улази спојни вокал -о-, именичка основа век- и суфикс -ан/-ни. ${ }^{9}$ Епитет кратковечан у делу носи Хектор, коме се не предвиђа дуг живот.

Посебну групу чине сложенице чији придев у првом делу означава неку боју. Такви су примери белозуб, белорук, мрковлас, мркокљун и ирнооблачан. Придеви у саставу наведених сложеница су контрастни - бео : ирн/ мрк. Прве три сложенице са придевом за боју у првом делу имају на другом месту основе именица које значе део тела човека или животиње. Према

\footnotetext{
${ }^{8}$ Овим придевима посебну пажњу посветио је С. Ракић у својој студији $O$ придевским сложеницама типа придев + именица (1998).

${ }^{9}$ Придев кратковечан има и дублетни облик кратковек, који садржи нулти суфикс. Међутим, лексема кратковек није забележена у проучаваном извору.
} 
томе, јасна је жеља аутора да скрене пажњу на конкретну појединост на телу одређених људи или животиња. Сложени придев белозуб описује три животиње: пса, свињу и вепра. Жене у спеву попут Хере, Андромахе и Хелене добијају епитет белорука. Поред саме боје руку, овај придев упућује на особе које имају 'господске, нерадничке руке'. Бог Посејдон се, осим већ истакнутом особином да потреса Земљу, одликује и придевом мрковлас. Тиме се скреће пажња на изразито црну Посејдонову косу. Придевска сложеница мркокљун ван контекста би свакако могла означавати неку птицу са тамним кљуном. Друга компонента ове сложенице из дела јесте основа именице кљун, али са њеним секундарним значењем: 'шиљаста подводна избочина бродског прамца који је служио за пробијање непријатељског брода; предњи, истурени део прамца брода, лађе ${ }^{e}$. Стога се овим придевом у спеву описује лађа са тамним предњим делом. Бог Зевс као бог громова и муње долази из црних облака, па и носи епитет црнооблачан. Овај придев има у другом делу именичку основу облак- и суфикс - $а н /-н u$. Сви претходни примери са придевом за боју као првом саставницом имају нулти суфикс, а спојни вокал -о- је неизоставан.

Именичке основе грив- и кос- већ су учествовале у творби других придева овог типа. Али, ове основе јављају се у саставу сложених придева и са другачијом првом компонентом. Примери лепогрив и лепокос на првом месту имају придевску основу леn-, а у њихов састав улазе и спојни вокал -о- и нулти суфикс. За коње и кобиле наводи се да су лепогриви, док су лепокосе бројне Хомерове јунакиње ${ }^{10}$. Семантика ових придева проистиче из саставница сложенице. Синонимне лексеме брз и хитар део су сложених придева на месту прве компоненте. Јављају се у примерима брзоног и хитрокрил. Други део сложеница заузимају основе именица које значе део тела. ${ }^{11}$ У Хомеровом делу брзе ноге имају коњи, али и понеки јунаци попут Ахилеја, Ајаса и сл. Хитрим крилима одликује се јастреб. Пошто су и ови примери добијени сложено-суфиксалном творбом, основе повезује спојни вокал, а додат је и нулти суфикс. Са неким делом животињског тела у другом делу сложенице грађене по истом моделу јављају се и следећи примери: густогрив и криворог. Придевом густогрив описује се шлем ${ }^{12}$ или кацига. Ова заштита за главу представљена у Илијади украшена је густом гривом коња. Животиње са кривим роговима обично су описане придевом криворог, а као такве помињу се говедо, во и крава. Још две придевске сложенице овог типа са спојним вокалом -о- и нултим суфиксом јесу драгощенн и слав-

${ }^{10}$ Сложени придев лепокос описује 10 јунакиња у Маретићевом преводу: Лета, Хелена, Тетида, Атена, Хера, Хекамеда, Деметра, Аматеја, Аријадна и Ниоба.

${ }_{11}$ Основе ног- и крил- садрже и већ анализирани сложени придеви ветроног, медоног и дугокрил.

${ }^{12}$ Као што смо видели током анализе, шлемови су у извору описани и као коњогривни, што је идентично придевској сложеници густогрив. 
нолук. Лексема драгоцен користи се уз именицу злато, јер је оно скупоцено ('има велику цену'). Придев драг који учествује у грађењу ове сложенице по значењу се изједначава са придевом скуn. Бог Аполон представља се са луком и стрелом, па му зато и припада епитет славнолук. Први део ове сложенице чини основа придева славан. Корпус обухвата и сложене придеве који уз придевску и именичку основу не бележе спојни вокал или садрже суфикс -ан/-ни. Примери румендлак и широкобродан срећу се у обрађеном извору. Прва сложеница мотивисана је придевом румен ('који има тонове, нијансе црвене боје, црвенкаст, ружичаст ${ }^{e}$ ) и именицом длака. У њен састав улази и нулти суфикс, али нема спојног вокала. Длаку црвенкасте боје има во у Хомеровом делу. Море је описано као широкобродно, јер ту могу да плове велики, широки бродови. Овај сложени придев има спојни вокал -о-, а додата је и суфиксална морфема -ан/-ни.

Скоро половина целокупне грађе у свом првом делу има придевску основу. Други део ових сложеница најчешће је именичког порекла, док се у два примера јавља цео придев на другом месту. Спојни вокал -о- доминантан је и у овој групи примера, изузев лексема злопак и румендлак. У већини анализираних придевских сложеница позицију суфикса заузима нулта морфема, док три примера бележе суфикс - $а н /-н и$. Готово сви сложени придеви су семантички прозирни, осим неколико примера који су лексикализовани и захтевају увид у контекст (нпр. кратковечан).

\section{3. Сложени придеви са бројем као првом саставницом}

Сви примери који су мотивисани бројем настали су сложено-суфиксалном творбом. На другом месту налази се именичка или глаголска основа. У корпусу се издвајају само два придева (4\%) чија је прва саставница број.

Придевска сложеница четворострук потиче од збирног броја четворо и именице струк. Често се покрећу полемике поводом ове друге саставнице, те Клајн истиче да је она прилично „мутно мотивисана” (2002: 112). Најчешће се струк као друга саставница сложеница користи у значењу увећања. Пример четворострук служи да дочара изглед штита који је састављен од четири слоја, а можда и четири пута већи од стандардног. Лексема садржи и нулти суфикс.

Сложени придев дворезан састављен је од основе броја два, спојног вокала -о-, редуковане основе глагола резати и суфикса -ан/-ни. Овим придевом описује се посебна врста копља које има оштрице на оба своја краја, тј. двапут реже.

Иако се срећу само два придева са бројем у првом делу, њихов састав се прилично разликује: један има именичку основу на другом месту, а други глаголску, један садржи спојни вокал, други не, код једног се јавља нулти суфикс, а код другог - $а н /-н и$. Оно што их повезује јесте да се оба користе као одређење неког дела опреме ратника, нпр. штита или копља. 


\section{4. Сложени придеви са прилошким првим делом}

Преостали део грађе чине придевске сложенице које имају прилог на првом месту. Свих 8 ексцерпираних сложених придева са прилошким првим делом (16\%) има глаголски други део.

Три сложенице јављају се са прилогом брзо у првом делу: брзолет ${ }^{13}$, брзоморан и брзоплован. Други део ових придева чине редуковане основе глагола летети, морити и пловити. Сложени придев брзолет има нулти суфикс, а односи се на кобиле и коње који су веома брзи, па лете као птице. Уз стреле је придодат придев брзоморан и означава да су изузетно смртоносне ('брзо море, убијају'), док лађе које брзо плове дефинише лексема брзоплован. Ови сложени придеви садрже суфикс -ан/-ни. Антонимни прилог споро присутан је у сложеници спороходан. Грађен је по истом моделу (прилог $+\Gamma_{\mathrm{o}}+$ суфикс), а њиме су одређене животиње попут краве, говеда и вола, које се полако крећу, тј. споро ходају. Следећи пример јесте даљьометан. Ова сложеница мотивисна је прилогом даљно ('далеко') и глаголом метати ${ }^{14}$. Њоме се карактерише добар стрељач који далеко баца оружје, као и бог Аполон. Са нултим суфиксом у свом саставу издвајају се примери лепотек и многохран. Прва сложеница садржи прилог лепо и аористну основу глагола тећи. Према саставницама лексеме лепотек јасно је да се односи на неку воду, извор или реку. Епитет многохран резервисан је само за земљу, а састављен је од количинског прилога и редуковане основе глагола хранити. Придевска сложеница дугосекли грађена је од прилога дуго и радног придева глагола сећи. Овим примером описује се мач у Илијади који задаје велике посекотине непријатељима.

Сложени придеви који у првом делу имају неки прилог немају спојни вокал у свом саставу. Други део је најчешће глаголска основа са суфиксом, али јавља се и партицип (радни глаголски придев). Овакав модел грађења придевских сложеница у српском језику је веома продуктиван, јер се прилог налази у својој примарној функцији, а то је одређивање глагола испред кога стоји.

\section{3. Фреквентност употребе сложених придева у спеву}

Томо Маретић, преводећи Хомерову Илијаду, користио је постојеће сложенице, али и склапао нове како би сликовито дочарао богове, људе, животиње и оружја. Ти придеви обично су типски везивани за неке јунаке или богове, па су се при свакој њиховој појави и понављали. Фреквентност

\footnotetext{
${ }^{13}$ Поред придева брзолет, преводилац употребљава и лексему са другачијим суфиксом брзолетан.

${ }^{14}$ Овај глагол учествовао је и у мотивацији сложеног придева копљометан.
} 
анализираних придевских сложеница испитана је електронском претрагом у целом спеву сваког од ексцерпираних примера.

Најфреквентнија придевска сложеница је брзоног, јер се у Маретићевом преводу понавља чак 110 пута. Настала је по најпродуктивнијем творбеном типу за грађење сложених придева, а описује Ахилеја и друге значајне јунаке. У томе лежи узрок толике фреквентности ове лексеме. Придев боголик забележен је 57 пута и одређује читав каталог Хомерових јунака. Уз низ женских ликова употребљавају се сложенице белорук и лепокос, а обе се срећу по 30 пута. Остали сложени придеви са већом фреквентношћу у целом спеву су: Зевсови епитети громогласан (18) и ирнооблачан (13), Херин епитет волоок (16), лепогрив (16), штитоносан (14), ветроног (13), лепотек (11), мороплован (11) и коњогојан (10). Дублетни пар брзолет : брзолетан није подједнако фреквентан. Чешћи је облик са нултим суфиксом који се појављује два пута, док је други забележен само једанпут. Једном се јављају и придеви брзоморан, злопак и хитрокрил. Неке од других нискофреквентних сложеница су: ветрородан (2), дуговрат (2), дугогрив (2), дугокрил (2), земьотресан (2), коловозан (2), медоног (2), мукопатан (2), копљоносан (3), мрковлас (3) и мркокљун (3). Наведени придеви уврштени су у Речник срnскохрватскога кюижевног језика (РМС) са кратком одредницом и примером баш из Маретићевог превода Илијаде. Уз неке од њих наглашено је да се ради о кованици (нпр. брзоморан, густогрив).

Од укупно 51 примера колико је пронађено од 12. до 15. певања, 11 сложених придева не налази своје место у Речнику: брзоплован (3), даљнометан (17), дугосен (23), дугосекли (2), земљомичан (8), златотрон (4), крвавочрвен (2), многохран (17), румендлак (1), славнолук (3) и широкобродан (1). И међу овим лексемама има високофреквентних примера. Придев дугосен понавља се 23 пута и увек описује копље, а нешто мање многохран, који стоји уз именицу земља.

Скоро сви анализирани сложени придеви понављају се у преводу Хомеровог спева. Укупно 6 примера забележено је једанпут (12\%), а пронађени су баш у централним певањима Илијаде. Ипак, само 16 придевских сложеница јавља се више од 10 пута, што чини 31\% корпуса. Остали примери су мање заступљени, што сведочи о невеликој фреквентности Маретићевих придева у спеву.

\section{4. Закључак}

Творбеном и семантичком анализом сложених придева уочена је разноврсност поступака Тома Маретића у њиховом стварању. У првом делу сложеница налазе се именице (19), придеви (22), прилози (8) и бројеви (2), док су на месту друге саставнице именице (27), придеви (3), глаголи (19) и 
партиципи (2). Од именица које се јављају на другом месту сложених придева чак 18 означава неки део тела човека или животиње. У састав 40 сложених придева улази и спојни вокал -о-, а то чини 78\% целокупне грађе. Суфиксалну морфему садржи 46 примера (90\%), а од тога 26 има нулти суфикс, док је 20 са суфиксом -ан/-ни. Укупно 51 придевска сложеница гради се на основу 12 следећих творбених типова:

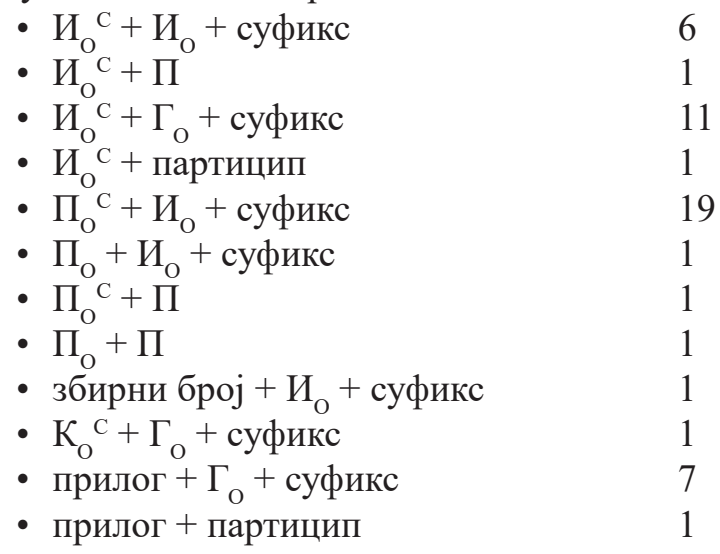

Прегледом свих творбених типова по којима су настали ексцерпирани примери уочен је доминантан модел њиховог грађења. Највише сложених придева (37\%) добијено је од придевске и именичке основе, спојног вокала и суфикса, што је и очекивано с обзиром на функцију придева као врсте речи. Већа група примера настала је и од именичке и глаголске основе са спојним вокалом и нултим суфиксом. Ово потврђује да је Маретић бирао придевске сложенице настале најпродуктивнијим типом творбе и по њима стварао нове. Анализирани придеви настали су сложено-суфиксалном творбом, док су ретки примери слагања (10\%). Познавањем њихових саставница лако се долази до значења сложеног придева. Само неколико сложеница процесом лексикализације стиче ново значење (нпр. ветроног, кратковечан). Аутор превода описује животиње користећи 13 придева из грађе, док уз помоћ других 9 одређује неко оружје или део опреме ратника. Остали примери упућују на богове, јунаке и др.

Испитиване лексичке јединице показале су да се у већини случајева понављају током дела. Сложени придев брзоног је најфреквентнији у делу, док се чак 6 примера јавља само једанпут. Приметан је и Маретићев поступак да извесну придевску сложеницу веже за одређену именицу, па да их тако као синтагму понавља. Ту спадају Зевсови и Посејдонови епитети, одређење лађе (брзопловна, моропловна и мркокљуна), описи копља (дугосено и медоковно) и сл.

На основу четири певања Илијаде извојено је доста разноврсних придева како у погледу грађења тако и у значењу којим се карактеришу број- 
не појединости Хомеровог света. Остала певања чувају још материјала за језичка истраживања. Томо Маретић је свакако обогатио домаћу лексику стварањем придева који доприносе сликовитости Хомеровог дела и улазе у једнојезичне речнике. Овим својим преводом створио је ново уметничко дело украшавајући га пажљиво бираним спојевима домаће лексике, чиме је на најбољи начин дочаран један свет књижевног дела.

\section{Цитирана литература}

КЛАЈН, Иван. Творба речи у савременом српском језику. Део 1, Слагање и префиксаиија. Београд: Завод за уџбенике и наставна средства, Институт за српски језик САНУ; Нови Сад: Матица српска, 2002.

ЛАШКОВА, Лили. „Из творбе придевских сложеница у српскохрватском и бугарском књижевном језику”. Научни састанак слависта у Вукове дане 16/1 (1987): 139-147.

ПИПЕР, Предраг и Иван Клајн. Нормативна граматика српског језика. Нови Сад: Матица српска, 2014.

РАКИЋ, Станимир. „О конверзији сложених придева у именице”. Наш језик XXXIV 1/2 (2001): 141-144.

РАТКОВИЋ, Драгана. „Чисте придевске сложенице са интерфиксом -о/е- у савременом српском језику". Српски језик: студије српске и словенске XV 1/2 (2010): 481-488.

PMC: Речник српскохрватскога књижевног језика, I-III. Нови Сад - Загреб: Матица српска - Матица хрватска, 1967-1969. IV-VI. Нови Сад: Матица српска, 1971-1976.

СТАНОЈЧИЋ, Живојин. „Есоцентричне придевске сложенице у српскохрватском књижевном језику”. Зборник Матище српске за филологију и лингвистику 27-28/1 (1984-1985): 727-732.

СТЕВАНОВИЋ, Михаило. Савремени српскохрватски језик. Део 1. Београд: Научна књига, 1986.

BABIĆ, Stjepan. Tvorba riječi u hrvatskom književnom jeziku. Zagreb: Hrvatska akademija znanosti i umjetnosti, 1991.

JOVANOVIĆ, Vladimir Ž. „Ograničenja i produktivnost u tvorbi pridevskih složenica”. Interkatedarska konferencija anglističkih katedri (2007): 57-77.

JOVANOVIĆ, Vladimir Ž. „Percepcija pridevskih složenica kod govornika srpskog jezika”. Језици и културе у времену и простору IV/2 (2014): 251-262.

JOVANOVIĆ, Vladimir Ž. „Problemi određivanja složenih prideva u engleskom i srpskom jeziku". Примењена лингвистика 3 (2002): 102-110.

MAKIŠOVA, Ana. „Pridevske složenice u slovačkom i srpskom jeziku”. Славистика XI (2007): 274-283. 
NEHRING, Gerd-Dieter. „Српски сложени придеви у поређењу са суседним језицима". Научни састанак слависта у Вукове дане 35/1 (2006): 339-352.

RAKIĆ, Stanimir. „O pridevskim složenicama tipa pridev + imenica”. Зборник Матице српске за филологију и лингвистику 41/1 (1998): 107-127.

\section{Извори}

HOMER. Ilijada. Preveo i protumačio Tomo Maretić. Zagreb: Matica hrvatska, 1948.

HOMER. Ilijada. Preveo i protumačio Tomo Maretić. <http://gimnazija-sb.com/ portal/wp-content/uploads/2015/02/homer_ilijada.pdf>30. 07. 2018.

Đorđe V. Šunjevarić

\section{COMPOUND ADJECTIVES IN MARETIC'S TRANSLATION OF HOMER'S POEM ILIAD}

The main concern of this paper is a word-formation and semantic analysis of compound adjectives used by Tomo Maretic in his translation of the 12. to 15. part of Homer's poem Iliad. The aim of this research is to determine the motivation, formation and frequency of these adjectives as well as to determine the dominant procedure of the translator. The central chapters, rich in events and characters, are expected to be abound in various adjectival compounds as well. 51 example has been excerpted. In order for the analysis to be more precise, all adjectives have been classified in four groups on the basis of the type of the word the first constituent of the compound belongs to. Compound adjectives where the adjectival base occupies the first place are the most numerous, then the ones whose base is nominal, and then those that contain an adverb, while only two adjectives in the first part have number. Connecting vowel $-o$ - is dominant, but the suffixes are also not rarely found ( $-\varnothing$ and $-a n /-n i)$. For this reason, $90 \%$ of the material has been obtained by compound-suffixal formation, and only five adjectives by composition (for example gromoglasan, krvavocrven). With regard to the meaning, most adjectives describe heroes and gods from Iliad. Some compound adjectives obtain lexicalized meaning (for example vetronog), whereas the majority retains the semantics of its constituents. The research of frequency indicates the repetition of the analized examples within Homer's poem (brzonog has been found 110 times). The analysis has also shown Maretic's process of connecting an adjectival compound to a certain noun, and in this way repeating them as a syntagm.

Keywords: compound adjectives, composition, compound-suffixal formation, Iliad 